\title{
Screening For Cushing's Syndrome in Primary Care: Which Test is The Best?
}

\author{
Vismay Naik* \\ Consultant Physician, Ashirvad Heart \& Diabetes Centre, India
}

Submission: March 23, 2017; Published: May 15, 2017

*Corresponding author: Vismay Naik, Consultant Physician, Ashirvad Heart \& Diabetes Centre, Gujarat, India, Email: vismay101@gmail.com

Keywords: Cushing's syndrome

Abbreviations: UFC: Urinary Free Cortisol; DST: Dexamethasone Suppression; CBG: Cortisol Binding Globulin; RIA : Standard Cortisol Radioimmunoassay

\section{Introduction}

Cushing's syndrome (CS) is defined as an outcome of prolonged exposure to glucocorticoids whether from outside or inside sources. It's a relatively rare condition with an incidence of 0.7-2.4 per million population per year [1]. Clinical presentation in primary care setting can be highly variable, and establishing the diagnosis can often be difficult and is frequently missed due to its rarity and overlapping characteristics with common disorders like metabolic syndrome. Early diagnosis and treatment of CS is associated with a decrease in morbidity and mortality [2]. The objective of this article is to discuss the most appropriate screening test that could be performed in primary care in clinically suspected cases of CS.

\section{Etiology of Cushing's Syndrome}

Exogenous administration of glucocorticoids (Iatrogenic CS) is the most common cause of CS. Table 1 shows the various causes of endogenous CS. ACTH dependent CS accounts for $80-85 \%$ of cases, of which around $75-80 \%$ are due to pituitary adenoma. Chronic alcoholism, depression and severe obesity may lead to reversible hyperactivity of HPA axis and cause pseudo-CS [1,2].

Table 1: Causes of Endogenous CS [2] ACTH- Adrenocorticotrophic hormone, $\mathrm{CRH}$-Corticotrophic releasing hormone.

\begin{tabular}{|c|c|}
\hline ACTH Dependent & ACTH Independent \\
\hline $\begin{array}{c}\text { Pituitary dependent CS } \\
\text { (Cushing's disease) }\end{array}$ & Adrenal adenoma \\
\hline Ectopic ACTH syndrome & Adrenal carcinoma \\
\hline Ectopic CRH-secreting tumor & $\begin{array}{c}\text { Primary pigmented nodular } \\
\text { adrenal disease. McCune-Albright } \\
\text { syndrome. Macronodular } \\
\text { and Micronodular adrenal } \\
\text { hyperplasia }\end{array}$ \\
\hline
\end{tabular}

\section{Clinical Features of Cs}

Table 2 discusses the various clinical features of CS. Certain features of the skin, muscles and bones are specific for CS that helps to differentiate it from simple obesity. Clinical features like cataract, raised intraocular pressure, aseptic necrosis of femoral head and osteoporosis are more common in iatrogenic CS [1].

Table 2: Clinical Feature of CS [12] DVT: Deep vein thrombosis.

\begin{tabular}{|c|c|}
\hline Specific Features & General Features \\
\hline \multirow{2}{*}{$\begin{array}{l}\text { Body - Abnormal fat deposition } \\
\text { leading to Weight gain, obesity, } \\
\text { moon face, buffalo hump. }\end{array}$} & $\begin{array}{l}\text { Cardovascular system- } \\
\text { Hypertension, hypokalemia, } \\
\text { edema, atherosclerosis. }\end{array}$ \\
\hline & $\begin{array}{l}\text { Metabolism- Diabetes } \\
\text { mellitus/glucose intolerance, } \\
\text { dyslipidemia, }\end{array}$ \\
\hline $\begin{array}{l}\text { Skin- Purple striae, facial } \\
\text { plethora, thin and brittle skin, } \\
\text { easy bruising, acne, hirsutism. }\end{array}$ & $\begin{array}{l}\text { Reproductive system-Decreased } \\
\text { libido, menstrual irregularities } \\
\text { in women mainly amenorrhea } \\
\text { due to reduced gonadotrophin } \\
\text { secretion due to effect of cortisol }\end{array}$ \\
\hline $\begin{array}{l}\text { Bone- Osteopenia, osteoporosis, } \\
\text { mainly involving the vertebrae } \\
\text { leading to reduced linear growth. }\end{array}$ & $\begin{array}{l}\text { Central nervous system- } \\
\text { Irritability, depression, cognitive } \\
\text { defects, paranoid psychosis. }\end{array}$ \\
\hline $\begin{array}{l}\text { Muscle- Weakness and proximal } \\
\text { myopathy }\end{array}$ & $\begin{array}{l}\text { Blood and immune system- } \\
\text { Hypercoagulation with risk of } \\
\text { DVT or pulmonary embolism and } \\
\text { susceptibility to infections. }\end{array}$ \\
\hline
\end{tabular}

\section{Whom to Screen}

Although CS is relatively rare, studies of patients with diabetes, obesity, hypertension, and osteoporosis found a high prevalence of CS among these populations [3]. The Endocrine Society guidelines recommend screening under the following circumstances: [4] 


\section{Current Research in Diabetes \& Obesity Journal}

- $\quad$ Patients with multiple, progressive, and discriminatory findings suggestive of CS.

- $\quad$ Cases with unusual features like hypertension or osteoporosis at a young age

- Children with a decreasing height percentile and increasing weight

- Adrenal incidentalomas

- $\quad$ Patients with familial disease that puts them at risk of CS.

- It recommends against widespread testing for CS other than the above patient group.

Screening Tests for Cushing's Syndrome in Primary Care Settings (Table 3)

Table 3: Screening Tests for CS [2] UFC- Urinary free cortisol, OCPOral contraceptive pills.

\begin{tabular}{|c|c|c|c|}
\hline Test & Method & Cut-off value & Remarks \\
\hline $24 \mathrm{hr}$ UFC & $\begin{array}{l}\text { Two samples } \\
\text { to be } \\
\text { collected and } \\
\text { refrigerated }\end{array}$ & $\begin{array}{c}>300 u g / \text { day } \\
\text { Sensitivity- } \\
90 \% \\
\text { Specificity- } \\
96 \%\end{array}$ & $\begin{array}{c}\text { False Positive: } \\
\text { Excess water } \\
\text { intake, } \\
\text { drugs like } \\
\text { carbamazepine } \\
\text { False Negative: } \\
\text { Renal } \\
\text { impairment }\end{array}$ \\
\hline $\begin{array}{c}\text { Late Night } \\
\text { Salivary Cortisol }\end{array}$ & $\begin{array}{l}\text { Two samples } \\
\text { between } 11 \mathrm{pm} \\
\text { and } 12 \mathrm{am}\end{array}$ & $\begin{array}{c}>145 \mathrm{ng} / \mathrm{ml} \\
\text { Sensitivity } \\
>90 \% \\
\text { Specificity } \\
92 \%\end{array}$ & $\begin{array}{c}\text { False Positive: } \\
\text { oral licorice, } \\
\text { tobacco, altered } \\
\text { day, night cycle, } \\
\text { stress }\end{array}$ \\
\hline $\begin{array}{c}\text { Overnight } \\
\text { Dexamethasone } \\
\text { suppression test } \\
\text { (DST) }\end{array}$ & $\begin{array}{c}\text { Oral } \\
\text { dexamethasone } \\
(1 \mathrm{mg}) \text { at } 11 \mathrm{pm} \\
\text { and serum } \\
\text { cortisol } 8 \mathrm{am}, \\
\text { next morning }\end{array}$ & $\begin{array}{c}>1.8 \mathrm{ug} / \mathrm{dl} \\
\text { Sensitivity } \\
>90 \% \\
\text { Specificity } \\
80 \%\end{array}$ & $\begin{array}{l}\text { False positive: } \\
\text { drugs like } \\
\text { phenytoin, } \\
\text { pregnancy, } \\
\text { OCP. Test can } \\
\text { be affected by } \\
\text { variability in } \\
\text { absorption and } \\
\text { metabolism of } \\
\text { dexamethasone }\end{array}$ \\
\hline Low dose DST & $\begin{array}{c}\text { Oral } \\
\text { dexamethasone } \\
0.5 \mathrm{mg} \text { 6hrly for } \\
2 \text { days, serum } \\
\text { cortisol level } \\
6 \text { hrs after the } \\
\text { last dose }\end{array}$ & $>1.8 \mathrm{Ug} / \mathrm{dl}$ & \\
\hline
\end{tabular}

It is recommended by the Endocrine Society guidelines [4] that one of the following tests be performed for screening of CS:

1. $24 \mathrm{hr}$ Urinary free cortisol (UFC) (at least two measurements)

2. Late-night salivary cortisol (two measurements)

3. 1-mg overnight Dexamethasone Suppression Test (DST)

\section{Longer low-dose DST (2mg/d for $48 \mathrm{~h}$ )}

\section{4hr UFC}

$24 \mathrm{hr}$ UFC looks at the unbound cortisol secretion that is filtered by the kidneys over a $24 \mathrm{hr}$ period and is not affected by conditions and medications that alter Cortisol Binding Globulin (CBG). Normal values: <90 microgram/24hours (250nmol/ day). Values more than 300microgram/day (830nmol/day) are considered diagnostic. Sensitivity of this test in detecting cortisol excess is $95 \%$, specificity is $98 \%$. False positive and false negative results may occur (Table 3 ). UFC should be confirmed with repeat testing [5].

\section{Late night salivary cortisol}

Physiological cortisol secretion follows a circadian rhythm. Serum cortisol concentration reaches its peak in the morning (0600-0800h) and is lowest in the night during the first half of normal sleep. Normal circadian rhythm of cortisol secretion is lost in patients with CS. Salivary cortisol is measured at 23:00 hours and 07:00 hours using a standard cortisol radioimmunoassay (RIA). The upper limit of reference range is $145 \mathrm{ng} / \mathrm{dl}(3.6 \mathrm{nmol} / \mathrm{L})$ and sensitivity is $>92 \%$. LNSF is a simple and reliable screening test for spontaneous Cushing's Syndrome and useful for screening large, high risk population (patients with diabetes mellitus) [4].

\section{Dexamethasone suppression test (DST)}

In standard DST patient is given $1 \mathrm{mg}$ dexamethasone orally at $11 \mathrm{pm}$ and the plasma cortisol level is measured at $8 \mathrm{am}$ next morning. In the 48-h low dose DST test, dexamethasone is given at the dose of $0.5 \mathrm{mg}$ every $6 \mathrm{~h}$ for 2 days at $090 \mathrm{~h}, 1500 \mathrm{~h}, 2100 \mathrm{~h}$, and $0300 \mathrm{~h}$ with measurements of cortisol in serum 6 hours after the last dose of dexamethasone (normal<1.8ug/dl). The sensitivity of this test is $98 \%$; specificity is $80 \%$. Normal findings in both the test make CS unlikely. Obesity, chronic illness, chronic alcoholism and depression can cause false positive results (pseudo-Cushing syndrome) [5].

\section{Discussion}

Cushing's syndrome is a relatively rare condition [6], and can present to primary care in many different ways, making the diagnosis a challenging one to reach. It is an important diagnosis to consider, as it has a significant impact upon morbidity and mortality, and early detection and treatment can have a significant impact on improving life expectancy [7]. Unfortunately, however, it is a diagnosis that is frequently 'missed', with a mean time to diagnosis of 6 years in one study [8].

In the primary care setting, the ideal first-line screening test would be very sensitive (ie. all those with Cushing's syndrome would be detected, and none would be missed), practically possible in the community, acceptable to the patient and costeffective [6]. 


\section{Current Research in Diabetes \& Obesity Journal}

Around the world all other tests except $24 \mathrm{hr}$ UFC, need to be performed in the hospital setting so the most readily available in the primary care setting is the $24 \mathrm{hr}$ UF [9]. $24 \mathrm{hr}$ UFC looks at the unbound cortisol secretion that is filtered by the kidneys over a $24 \mathrm{hr}$ period. This test is usually considered overall to have a high diagnostic sensitivity in adults and children, it is important to correlate test results with creatinine ratios to ensure a complete collection [4]. This test also has multiple external factors that can cause or mask false negative/positive results such as excess fluid intake, certain medications and improper collections. It is vital to obtain a thorough assessment to take place to accurately access results. [3]. In the pediatric population, even with a high sensitivity of $89 \%$ it is still recommended to follow up the UFC with a second test mentioned above to confirm a diagnosis [10].

24 hour urinary free cortisol levels appears to be the most practical first-line test to perform in primary care in patients where there is a high probability of Cushing's Syndrome, because it is non-invasive and widely available [8]. However, in patients who have a lower probability of Cushing's syndrome, it may be advantageous to consider late night salivary cortisol or 1-mg overnight dexamethasone, because both of these tests are more sensitive, reducing the likelihood of false negative results [8]. Unfortunately, late night salivary cortisol is not a test that is widely available to primary care physicians in the UK [11]. The $1 \mathrm{mg}$ overnight dexamethasone suppression test is possible to organize in primary care, with a well motivated patient, but the practicalities of timing the administration of the drug and the blood test, make it slightly more of a challenge [12].

\section{Conclusion}

In summary, when screening for Cushing's syndrome in primary care in the UK, a 24hour urinary free cortisol level is a useful test for the majority of patients, particularly when they have symptoms that make the diagnosis of Cushing's Syndrome likely. In a patient who is less likely to have Cushing's Syndrome, but needs screening to exclude the diagnosis, $1 \mathrm{mg}$ overnight dexamethasone testing may be preferable, due to the higher sensitivity of the test.

\section{References}

1. Sharma ST, Nieman LK, Feelders RA (2015) Cushing's syndrome: epidemiology and developments in disease management. Clin Epidemiol 7: 281-293.

2. Lila AR, Sarathi V, Jagtap VS, Bandgar T, Menon P, et al. (2011) Cushing's syndrome: Stepwise approach to diagnosis. Indian J Endocrinol Metab 15(4): S317-S321.

3. Guaraldi F, Salvatori R (2012) Cushing syndrome: may be not so uncommon of an endocrine disease. J Am Board Fam Med 25(2): 199208.

4. Nieman LK, Biller BM, Findling JW, Newell PJ, Savage MO, et al. (2008) The diagnosis of Cushing's syndrome: an endocrine society clinical practice guideline. J Clin Endocrinol Metab 93(5): 1526-1540.

5. Castro MD, Moreira AC (2007) Screening and diagnosis of Cushing's syndrome. Arq Bras Endocrinol Metabol 51(8): 1191-1198.

6. Guignat L, Bertherat J (2010) 'The diagnosis of Cushing's syndrome: an Endocrine Society Clinical Practice Guideline: commentary from a European perspective.' European Journal of Endocrinology 163(1): 9-13.

7. Petersenn S, Newell PJ, Findling JW, Gu F, Maldonado M, et al. (2014) 'High variability in baseline urinary free cortisol values in patients with Cusching's disease.' Clinical Endocrinology 80(2): 261-269.

8. Prague JK (2013) ‘Cushing’s Syndrome.' BMJ 346: f945.

9. Hurley DM, Ho KK (2004) 9: Pituitary disease in adults. Medical journal of Australia 180(8): 419-427.

10. Brook CG, Dattani MT (2012) Handbook of clinical pediatric endocrinology. John Wiley \& Sons, Inc., USA pp. 368.

11. Lapworth R, Vickery S (2014) Cushing's Sydrome: Guidelines for Investigation. East Kent Hospitals University NHS Trust 1-18.

12. Sulentic P, Morris DG, Grossman A (2014) 'Cushing's Disease'. In: De Groot LJ, Beck PP, Chrousos G, et al. (eds.) Endotext [Internet].

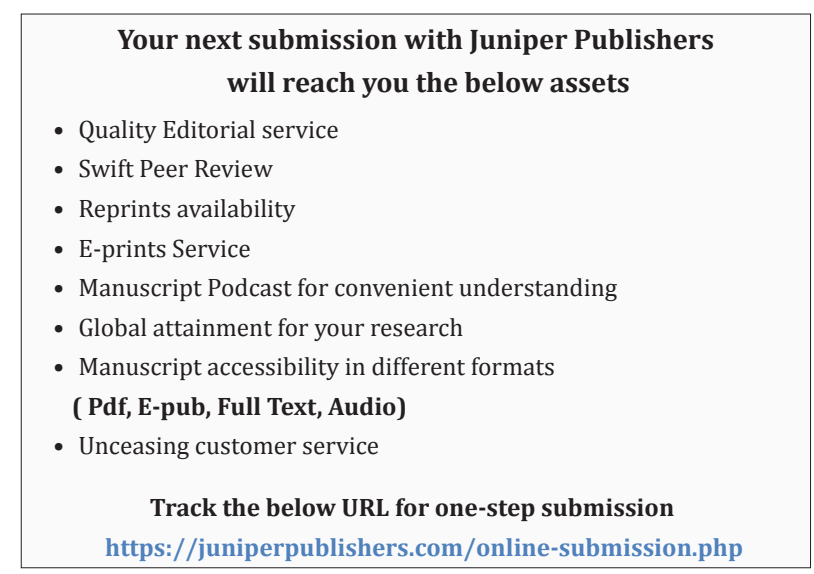

